\title{
An Empirical Investigation Of The Concept Of Consumer Service Satisfaction: A Tricomponent Model
}

F. Ruth Smith, Savannah State University, USA

Carroll A. Brown, Western Carolina University, USA

\begin{abstract}
The concept of consumer satisfaction has been heavily researched with little agreement on its proper measurement. A tricomponent model is offered which is simple, robust, easily administered, and understandable to marketing managers.
\end{abstract}

Keywords: Consumer satisfaction, measurement, model, festivals, satisfaction domain

\section{INTRODUCTION}

n the last forty years, the concept of consumer satisfaction has been heavily researched. During the latter
part of this time, satisfaction with services has received much attention. Despite this, there is considerable
debate on the conceptualization of the construct of consumer satisfaction and its measurement.

Customer satisfaction is generally " conceptualized as an attitude like [sic] judgment following a purchase act or based on a series of product-consumer interactions" (Fournire and Mick, 1999, 5). Research into consumer satisfaction has approached its conceptualization and measurement from two distinct theoretical perspectives: expectation confirmation/disconfirmation (Anderson, 1973, Day 1977, Churchill and Suprenant) and the attributional approach considering the psychological distance between the product/service and the individual's ideal product/service in a multidimensional space representing the salient product/service attributes (Day, 1977, Smith et al 1986). Most studies using the confirmation/disconfirmation of expectations approach have used one of three psychological theories as frameworks: cognitive dissonance or assimilation theory, contrast theory, and assimilationcontrast theory (Smith et al 1986). The attributional approach conceives of the consumer as a rational decisionmaker who maximizes utility and satisfaction and who implicitly or explicitly evaluates the cause of the performance (Valle and Wallendorf 1977). The attributional approach is highly abstract, however it does provide an elegant model whereby the consumer experiences satisfaction or dissatisfaction with not only the product/service itself, but the experiential elements which accompany its consumption. As Wirtz and Lee 2003) point out, as "research on consumption experience grows, evidence suggests that consumers purchase goods and services for a combination of two types of benefits: hedonic and utilitarian" (p.3). Utilitarian benefits are associated with the instrumental or functional aspects of the product/service and are cognitive (Batra and Athola 1990); whereas, hedonic benefits are the expressive or pleasing properties (sensory benefits)of a product/service and its acquisition and are affective(Mano and Oliver 1993). Most satisfaction research has focused on the materialistic aspects of satisfaction, or the utilitarian benefits. Services are sometimes completely intangible and have no material attributes, thus the researcher must examine satisfaction with the expressive benefits. The purpose of this paper is to examine the concept of consumer satisfaction with a service which combines material or instrumental benefits from the product component of the service, with the expressive benefits of the consumption process, and with the mechanisms allowing access to the service. 


\section{MEASURING SERVICE SATISFACTION}

Research by Smith, Bloom, and Davis (1988) in the area of patient satisfaction suggests a tricomponent model which conceptualizes the satisfaction domain as consisting of three dimensions: instrumental, or the functional attributes of a produce/service such as quality; expressive, or the hedonic aspects of the service such as staff helpfulness; and access mechanisms, such as price, parking, and waiting times. The model's "integrative taxonomy achieves considerable parsimony by classifying a wide range of attributes into three useful and empirically stable dimensions" (Mishra et al 199?, p 22). Although developed by measuring patient satisfaction, the tricomponent model is suggested as a general model of consumer satisfaction because it is simple, captures specific and overall satisfaction levels with a variety of attributes, is easily administered, and has been found superior to other models which may have been more psychometrically rigorously developed (Mishra et al 2004, Singh 1988). Its simplicity is deceptive, however, because the three dimensions together seem capable of inclusion of any attribute of the service, including material, or product, attributes as part of the total satisfaction experience as well as the ease or difficulty of access to the service. This tricomponent model of consumer satisfaction has been used by other researchers in patient satisfaction research (Singh 1988, Mishra et al) because of "its apparent stability and consistency over several studies" (Mishra et al, 2004, p.18). Also, it has been found superior to the SERVQUAL model (Parasuraman, Ziethaml, and Berry, 1988) in Mishra, Singh and Wood, 2004). The original authors suggest the model may be used in other contexts, as well, to examine its ability as a general consumer satisfaction model with both services and products. In this paper, satisfaction with a tourism event, a local arts festival, is examined within the framework of the tricomponent model.

\section{FESTIVALS}

Since the early 1990's, festivals and special events have emerged as new forms of special interest tourism, evolving into a global industry. According to Weiler and Hall (1992), special interest tourism can be described as "specialized tourism involving group or individual tours by people who wish to develop certain interests and visit sites and places connected with a specific subject" (p. 5). There is a growing interest in festivals and events on the international, national, state and local levels (Yeoman, Robertson, Ali-Knight, Drummond \& Beattie, 2004). For example, in rural areas, special interest tourism has been undertaken through such activities as local festivals, sightseeing nature tours, and heritage events. In recent years, small towns have begun to use local festivals as part of an economic development strategy to attract tourists, realizing that festivals can be important attractors for destinations and can provide unique experiences for visitors (Kim \& Uysal, 2003).

Rural festivals increase the demand for local tourism, help re-create the image of a place and extend the tourism season (Gursoy, Kim \& Uysal, 2002; Yoon, Spencer, Holecek, \& Kim, 2000). These festivals have become increasingly popular as an important means of revitalizing rural towns, preserving and promoting the history and regional culture, providing recreation and leisure opportunities, and boosting the local economy. (Brown, 2007; Long \& Perdue, 1990; Wachsman, 2004). Consequently, "their sustained popularity has made it important to identify new markets to help retain the tourism interest in the midst of economic recession and competition." (Long \& Perdue, 1990). Recently, festival producers have come to understand that identification and analysis of their various target market segments are important to the understanding of why some people attend and others do not (e.g., Getz 1990). Increased competition between visitor destinations and the high cost of promotion encourage marketing specialists and event organizers to identify the behavioral characteristics of visitors they intend to service" (Mc Cleary 1995, p.175). An understanding of consumer satisfaction encourages the development of event opportunities that lead to successfully marketed festivals.

\section{DATA COLLECTION}

Mountain Heritage Day is an annual festival held in Cullowhee, North Carolina which celebrates and showcases local arts, crafts, customs, and food. In an attempt to understand their market, the promoters developed a questionnaire designed to discover what areas of customer service do and do not need improvement, what promotions might be effective, and what information is needed to attract sponsorship. A two-page questionnaire was 
used to collect attendee demographics, their motivations for attending the festival, how long and where they stayed, how they knew about the festival, and what aspects of the event they found satisfactory. A convenience sampling design used a student-administered questionnaire completed at the festival grounds for the duration of the festival. The population included the estimated 25,000 visitors in attendance at the Mountain Heritage Day festival on September 30, 2006. The sampling frame included all people who appeared to be at least 18 years old on the festival grounds between 9:00 am and 3:00 pm. Each of twenty-seven students asked individuals from the sampling frame to complete the survey. A total of 348 responses was collected.

\section{RESULTS}

Results indicate that most attendees are local residents who specifically intend to attend the festival and who plan to attend next year. Another one-third traveled from neighboring North Carolina counties. Only 16\% were from out of state, and of those over a third stayed in hotels for at least two days. The majority of visitor samples were between the ages of 42 and 61 (Baby Boomers). Regarding satisfaction with different aspects of the festival, the attributes considered most salient to the promoters of MHD fit the tricomponent satisfaction model and include instrumental attributes (quality and variety of food, arts, crafts), expressive attributes (layout, helpfulness of staff), and access mechanisms (prices, parking, access to restrooms). These attributes were placed a priori into the appropriate categories. There were two items representing expressive attributes and three each for instrumental and access mechanisms. Figure 1 depicts the model together with the a priori classification of scale items. Each was measured with a Likert scale, from Strongly Agree (5) to Strongly Disagree (1). An open-ended question asked for any specific comments on satisfaction with any aspect of the festival, as well.

Figure 1: Tricomponent Model of Service Satisfaction

Instrumental Dimension
Quality of Crafts
Variety of Crafts
Quality of Food

Instrumental Dimension

Quality of Food
Expressive Dimension

Helpfulness of staff

Physical Layout of Festival Grounds
Access Mechanisms Dimension

Parking

Restrooms

Price of Food

Table 1: Analysis of Variance

\begin{tabular}{|c|c|c|c|c|c|c|}
\hline Source & DF & SS & MS & \multicolumn{3}{|c|}{$\mathrm{P}$} \\
\hline Factor & 2 & 503.72 & 251.86 & 251.86 & \multicolumn{2}{|l|}{0.000} \\
\hline Error & 1035 & 1035.00 & 1.00 & & & \\
\hline Total & 1037 & 1538.72 & & & & \\
\hline & & & & \multicolumn{3}{|c|}{$\begin{array}{l}\text { Individual 95\% CIs For Mean } \\
\text { Based on Pooled StDev }\end{array}$} \\
\hline Level & $\mathrm{N}$ & Mean & StDev & --------+---- & \multirow{4}{*}{\multicolumn{2}{|c|}{$(-*$}} \\
\hline Inst & 348 & 5.633 & 1.000 & & & \\
\hline Expr & 348 & 4.955 & 1.000 & & & \\
\hline A M & 348 & 3.938 & 1.000 & $(-*)$ & & \\
\hline Pooled StDev = & & 1.000 & & 4.20 & 4.80 & 5.40 \\
\hline
\end{tabular}

In order to assess whether the 8-item satisfaction scale did, in fact measure the three proposed dimensions of the model, the appropriate items were summed, standardized, and analyzed for variance. ANOVA showed significant differences among them $(\mathrm{F}=.251, \mathrm{p}=.001)$. As Table 1 indicates, respondents were most satisfied with the functional attributes of the festival: food, music, arts, and crafts. They were least satisfied with access mechanisms, parking, prices, and restroom facilities. Smith, Bloom and Davis (1986) suggest that in the patient satisfaction area, respondents may indicate high levels of satisfaction on the structured items of the quantitative scale but then contradict themselves by mentioning not being so satisfied with certain attributes in the open-ended question, and 
they suggest that researchers should examine both. Analysis of the MHD comments revealed some such contradiction. Although structured responses indicated satisfaction with MHD offerings, the open-ended questions reflected dissatisfaction. Almost all open-ended comments were related to restrooms, parking, prices, and waiting lines: the access mechanisms, found to be the quantitatively least satisfactory dimension of the model in this case. This finding supports that of Smith et al. and suggest open-ended items should always be included in satisfaction measures.

There are limitations to this study. The data collection instrument was designed by the MHD promoters, and a balanced number of items for each dimension of the model would have been better, as would a larger number of attributes for each dimension. Although data collection occurred during much of the festival, there may be selection bias, even though student surveyors were cautioned against it.

\section{IMPLICATIONS}

Implications of the findings are both general and specific. In general, the tricomponent model serves well in the measurement of satisfaction with a service. It also reveals that, in the case of the Mountain Heritage Day festival, the instrumental attributes of the festival may the most satisfactory to consumers. The expressive attributes, staff helpfulness and grounds layout, are second in satisfaction levels. Attendees may not, however, be as satisfied with access mechanisms. Respondents find the food prices too high, waiting lines too long, and are not satisfied with the restrooms and the parking situation. These lower satisfactions would seem the easiest to remedy, and the promoters of MHD should work to address these areas. More, cleaner restrooms could be added by contract with a local provider. Parking areas could be added by temporarily renting surrounding space from owners. Food vendors will most likely not lower prices, but they could add one or two more people to help serve visitors, thus shortening their waiting times. They could also offer small or half-portions for less money.

\section{FUTURE RESEARCH}

These results lend further support to the tricomponent model of satisfaction. This simple, parsimonious model should be tested with a wider variety of services and products. If it continues to be found useful, managers should appreciate its simplicity, its comprehensibility, its ease of use, and its parsimony. Managers may find that using this model is a quick but robust way to assess consumer satisfaction of their service offerings.

For MHD and other festival promoters, an approach which assesses "customer delight" may be useful. Customer delight is described as "going beyond satisfaction to delivering what can be best described as a pleasurable experience for the client" (Patterson, 1997, p. 222). It can be measured by having respondents list their 3 most satisfactory experiences of the festival and their three least satisfactory ones (Crotts and Pan,2007; Pritchard \& Havitz, 2005, 2006). "Delighted" customers can provide competitive advantage by promoting customer retention, loyalty, positive word of mouth, and profitable operations (Torres \& Kline, 2006).

\section{AUTHOR INFORMATION}

F. Ruth Smith is an Associate Professor of Marketing in the College of Business Administration at Savannah State University. Her areas of research and publication are elderly consumers, marketing modeling, serious leisure. She received a Ph.D. and MBA from Georgia State University and a BA in Economics from Agnes Scott College. Email: smithf@savstate.edu.

Carroll A. Brown is an Assistant Professor in the Department of Sales, Marketing, Hospitality and Tourism Department in the College of Business at Western Carolina University. Her areas of research and publication are cultural tourism, special interest tourism, serious leisure, aging, recreational specialization, and social world theory. She received a Ph.D. from Clemson University in Parks, Recreation, and Tourism Management, a M.B.A. in marketing from the Citadel, and a B.S. in Management from the College of Charleston. Email: cabrown@wcu.edu. 


\section{REFERENCES}

1. Anderson, R. (1973). Consumer Dissatisfaction: The Effect of Discconfirmed Expectations on Perceived Product Performance. Journal of Marketing Research, 38-44.

2. Batra, R. and Athola, O. (1990) Measuring the Hedonic and Utilitarian Sources of consumer Attitudes. Marketing Letters. 2(2), 159-170.

3. Brown, C. A. (2007). The history and evolution of the shag: A Carolina tradition. North Carolina Folklore Journal. 54(1), 18-32.

4. Churchill, G. and Suprenant, C. (1982). An Investigation into the Determinants of Consumer Satisfaction. Journal of Marketing Research, 19(4), 491-504.

5. $\quad$ Crotts, J. C. and Bing Pan (2007). Destination appraisals. Annals of Tourism Research, 34(2), 541-544.

6. Day, R. (1977). Toward the Process Model of Consumer Satisfaction. Conceptualization and Measurement of Consumer Satisfaction and Dissatisfaction, (ed.) K.Hunt, Cambridge: Marketing Science Institute, 153.

7. Formica, S. \& Uysal, M. (1996). A market segmentation of festival visitors: Umbria jazz festival in Italy. Festival Management \& Event Tourism, 3, 175-182.

8. Fournier, S. and Mick, D. (1999). Rediscovering Satisfaction. Journal of Marketing, 63(4), 5, 19.

9. Getz, D. (1990). Festivals, special events, and tourism. New York: Van Nostrand Reinhold.

10. Gursoy, D., Kim, K., \& Uysal, M. (2002). Perceived impacts of festivals and special events by organizers: An extension and validation. Tourism Management, 25, 171-181.

11. Kim, K. and Uysal, M. (2002 ). Perceived socio-economic impacts of festivals and events among organizers. Journal of Hospitality and Leisure Marketing, 10(3/4), 159-171.

12. Long, P. and Perdue, R. (1990). The economic impact of rural festivals and special events: Assessing the spatial distribution of expenditures. Journal of Travel Research, 28(4), 10-14.

13. Mano, H. and Oliver, R. (1993). Assessing the Dimensionality and Structure of the Consumption Experience: Evaluation, Feeling, and Satisfaction. Journal of Consumer Research, 20(4), 451-456.

14. McCleary, K. (1995). Applying internal marketing techniques for better festival organization and management. Festival Management \& Event Tourism, 3(1), 1-7.

15. Mishra, D., Singh, J., and Wood, V. (2004). An Empirical Investigation of Two Competing Models of Patient Satisfaction. Ed. C. Schewe, Marketing Management Issues in Ambulatory Health Care, Boston.

16. Patterson, K. (1997). Delighted customers are loyal clients, Rough Notes, 140(3). 221-34.

17. Pritchard, M. \& Havitz, M. (2006). Destination appraisal: An analysis of critical incidents. Annals of Tourism Research, 33(1), 25-46.

18. Parasuraman, A., Ziethaml, V., and Berry, L. (1988). SERVQUAL: A Milti-Item Scale for Measuring Consumer Perception of Service Quality. Journal of Retailing, 64(2), 12-40.

19. Pritchard, M. \& Havitz, M. (2005). Ratios of tourist experience: It was the best of times, it was the worst of times. Tourism Analysis, 10(1), 1-6.

20. Singh, J (1988) "The Patient Satisfaction Concept: A Review and Reconceptualization. Advances in Consumer Research, Ed. T. Srull.

21. Smith, R. B \& Bloom P. (1985). Research on Patient Satisfaction: Potential Directions. Advances in Consumer Research, 13, Provo, UT: Association for Consumer Research, 321-326.

22. Torres, E. N. \& Kilne, S. (2006). From customer satisfaction to delight: A model for the hotel industry. International Journal of Contemporary Hospitality Management. 18(4): 290-301.

23. Valle, V. and Wallendorf, M. (1977). Consumer Attributions as the Cause of Their Product Satisfaction and Dissatisfaction, R. Day (ed), Consumer Satisfaction, Dissatisfaction, and Complaining Behavior, Bloomington: Indiana University, 91.

24. Wachsman, Y. (2004). Society of Stranders fall migration: Analysis and economic impact. Conway, S. C: Coastal Carolina University, Coastal Federal Center for Economic and Community Development.

25. Weiler, B. and Hall, C.M. (1992). Special interest tourism. London: Belhaven Press.

26. Wirtz, J. and Lee, M. (2003). An Examination of the Quality and Context=Specific Applicability of Commonly Used Consumer Satisfaction Measures. Journal of Services Research, 5(4), 345-355.

27. Yeoman, I., Robertson, M., Ali-Knight, J., Drummond, S., \& McMahon-Beattie, U. (2004). Festival and events management. Oxford: Elsevier Butterworth-Heinemann. 
28. Yoon, S., Spencer, D., Holecek, S., \& Kim, K. (2000). A profile of Michigan's festival and special event tourism market. Event Management, 6, 33-44.

\section{NOTES}

